\title{
Matematiksel Muhakeme Becerileri Değerlendirme Ölçeğinin Geliştirilmesi ${ }^{1}$
}

\author{
DOI: 10.26466/opus.610197 \\ * \\ Halil Coban* - Erdoğan Tezci ** \\ * Dr, Milli Eğitim Bakanlığı, Çağatay Uluçay Ortaokulu / Manisa / Türkiye \\ E-Posta: cobanhalil@hotmail.com \\ ORCID: $\underline{0000-0001-6807-1380}$ \\ ** Prof. Dr., Balıkesir Üniversitesi, Necatibey Eğitim Fakültesi/ Balıkesir/ Türkiye \\ E-Posta: etezci@balikesir.edu.tr \\ ORCID: $\underline{0000-0003-2055-0192}$
}

$\ddot{O} z$

Çalışmanın amacı ortaokul öğrencilerinin matematiksel muhakeme becerilerini değerlendirmek için bir ölçek geliştirmektir. Literatür incelendiğinde ölçek geliştirme çalışmalarının madde havuzu oluşturma, uzman görüşü, ön uygulama ve geçerlik-güvenirlik çalışmalarının yapıldığ̆ aşamalar olmak üzere 4 aşamada yürütüldü̈̆̈̈ görülmektedir. Bu araştırmada 4 aşamayı da içinde barındıran Tracy ve Gibson (2005, s.40) tarafindan belirtilen aşamalar kullanılmıştır. Matematiksel Muhakeme Becerilerini Değerlendirme Ölçeği, öğrencilerin matematiksel muhakeme becerilerine ne düzeyde sahip oldukların ortaya koymayı amaçlamaktadır. Ölçek, literatürden yola çıkarak belirlenen matematiksel muhakemenin 7 alt boyutunu içeren 11'i çoktan seçmeli, 12'si kısa cevapl sorular olmak üzere iki kısımdan toplam 23 maddeden oluşmaktadır. Birinci kısım, matematiksel muhakemenin alt boyutlarından her birini ölçebilecek yeterli sayıda soru bulunabilmesi böylece kapsam geçerliğinin sağlanması amactyla çoktan seçmeli sorulardan, ikinci kısım ise matematiksel düşünme süreçlerini ortaya çıkarmaya firsat verecek sorulardan meydana gelmektedir. Ölçeğin alt boyutlan ise tahmin etme, aynı verinin farklı gösterimlerini tanıma, örüntüleri tanıma, çözüm yolunun ve sonucun doğruluğuna karar verme, genelleme, rutin olmayan problemleri çözme ve çözüm için mantıklı yollar geliştirme olarak belirlenmiştir. Sonuç olarak "Matematiksel Muhakeme Becerileri Değerlendirme Ölçeği"nin geçerli ve güvenilir olduğu ortaya konmuştur.

Anahtar Kelimeler: Matematiksel muhakeme, Matematiksel muhakeme ölçeği, Ölçek geliştirme, Ortaokul.

${ }^{1}$ Bu çalışma birinci yazarın hazırladığı doktora tezinden üretilmiştir. 


\title{
Developing The Mathematical Reasoning Skills Assessment Scale
}

\begin{abstract}
The aim of this study is to develop a scale in order to evaluate the mathematical reasoning skills of secondary school students. When the literature is examined, it is seen that the scale development studies are carried out in 4 stages: item pooling, expert opinion, pre-application and validity-reliability studies. In this study, the stages mentioned by Tracy and Gibson (2005, s.40) which includes 4 stages, were used. The scale for evaluating mathematical reasoning skills aims to determine the level of student's mathematical reasoning skills. The scale consists of 23 items, of which 11 are multiple choice questions and 12 are short answer questions, including 7 sub-dimensions of mathematical reasoning based on the literature. The first part consists of multiple choice questions to ensure that there is enough questions to measure each of the sub-dimensions of mathematical reasoning and the second part consists of questions that will give opportunity to reveal mathematical thinking processes. The sub-dimensions were identified as estimating, recognizing pattern, deciding the correctness of the solution and the result, generalizing, solving non-routine problems and developing logical ways to solve. As a result, "Mathematical Reasoning Skills Assessment Scale" was found to be valid and reliable.
\end{abstract}

Keywords: Mathematical reasoning, Mathematical reasoning scale, Scale development, Middle School 


\section{Giriş}

Günlük hayatta ve matematik dersinde karşılaşılan problemleri çözebilmek matematiksel olarak mantık yürütebilmeyle bir başka ifadeyle matematiksel yeterliliğe sahip olmayla yakından ilgilidir (Demir ve Akar-Vural, 2016). Kilpatrick ve Swafford' a göre (2002, s.9; Akt. Temizöz, 2013) Matematiksel yeterlilik terimi 5 bileşenden oluşmuştur ve bu bileşenler kısaca şu şekilde açıklanmıştır;

1. Anlama: Matematiksel kavramları, işlemleri anlama ve matematiksel işaret ve işlemlerin anlamını bilme

2. Hesaplama: Matematiksel işlemleri düzgün yapma.

3. Uygulama: Problemleri matematiksel olarak ifade etme, problemleri çözmek için uygun yollar bulma

4. Muhakeme: Bir problemin çözümünü gerekçelendirmek veya bilinenden bilinmeyene ulaşmak için akıl yürütme.

5. İlgi: Matematiği mantıklı bulma ve üzerinde çalışmaya istekli olma

Matematiksel yeterlilik için belirtilen bileşenlerin tümü oldukça önemli ve birbirini etkileyen bileşenlerdir. Ancak muhakeme becerisi, işlemlerin ve kavramların bir araya getirilmesindeki ve problem çözmede strateji geliştirmedeki rolü ve sonuçların gerekçelendirilmesine olanak sağladığı dikkate alındığında tüm bileşenleri bir arada tutan bir rol oynadığı ifade edilebilir (Brodie, 2010; Kilpatrick, Swafford ve Findell 2001).

Bireyin muhakeme edebilme becerisi, bireyin karşılaştıkları duruma uygun değerlendirme süreci içerisinde bulunmasını, yaptığı irdeleme neticesinde uygun tahminlerde bulunabilmesini ve düşüncelerini temellere dayandırarak açıklayabilmesini doğrudan etkiler (Umay, 2003). Literatürde yapılan birçok tanımdan (Altıparmak ve Öziş, 2005; Erdem, 2011; Lithner, 2006; MEB, 2013; Umay, 2003) yola çıkarak muhakeme kavramını; var olan bilgilerden hareketle karşılaştırma ve genellemeler yaparak bütün etmenleri de dikkate alarak düşüncelerini gerekçelere dayandırıp mantıklı bir sonuca ulaşma süreci olarak ifade etmek mümkündür. Bu bakımdan matematiksel düşüncenin ve anlayışın gelişmesi ve yeni edinilen matematiksel bilgilerin yapılandırılması için kısaca genel matematiksel yetenekleri geliştirmek için en çok ihtiyaç duyulan temel bir beceri olarak muhakeme becerisi oldukça önemlidir (Ball ve Bass, 2003; Herman vd., 2018). Özetle matematik alanının içerisinde muhakeme en çok başvurulan becerilerden biridir. Bu bağlamda 
matematiksel muhakemenin matematiğin temelini oluşturduğu ifade edilebilir (Pilten, 2008; Herman vd., 2018).

Matematiksel muhakeme, bireylerin karşılaştıkları durumlara matematiksel bakış açısıyla yaklaşarak sebep ve sonucunu araştırıp durumu anlamlandırma, matematiksel kavram ve sembolleri kullanarak mantıklı bir sonuca ulaşmaya yardımcı olacak muhakeme yapma becerisidir (Brodie, 2010; Erdem, 2015; MEB, 2013). Matematiksel muhakeme bireylerin matematiksel yeterliliğe ulaşmasını sağlayacak olan gerekçelendirme, genelleme, iletişim, temsil etme ve sembollerle ifade etme gibi becerileri içinde barındırır (Ball ve Bass, 2003; Brodie, 2010). Günhan (2014) ve Kilpatrick, Swafford ve Findell (2001), problem çözme ile matematiksel muhakeme arasındaki ilişkinin yüksek olduğuna dikkat çekmiştir. Gerek yurt içi gerek yurt dışı araştırmalarda matematiği anlamlı kılma ve matematiksel muhakeme becerisinin öğrencilere kazandırılması oldukça önemli görülmektedir (NCTM, 2000; MEB, 2017). NCTM (2000) matematik öğrenmenin amacını problem çözmeyi, muhakeme yapmayı ve iletişimi öğrenmek olarak ifade etmiştir. Bu bakımdan muhakeme öğrencilerin dikkat etmesi gereken matematiksel bir güçtür (Kadarisma vd., 2019). Matematiksel muhakeme, matematiksel kavramları anlamada matematiksel fikirler üretmede, yeni edinilen bilgileri yapılandırmada, işlemleri etkili ve esnek kullanmada kısaca matematiği anlamlandırma ve matematiksel uygulamalarda bir araç ve önemli bir beceri olarak ifade edilmektedir (Brodie, 2010; Ev-Çimen, 2008).

Literatür taraması neticesinde matematiksel muhakeme değerlendirme ölçeğine yönelik ölçek geliştirme çalışmalarını özellikle Türkiye' de çok az sayıda olduğu görülmüştür. Öğrencilerin matematiksel muhakeme becerilerine ne derece sahip oldukları belirlenerek geliştirmeye yönelik gerekli tedbirlerin öğretmenler tarafından alınması ya da matematiksel muhakeme becerilerini kullanmayı daha üst düzeye çıarmak için çalışmalar yapılması son derece önem arz etmektedir. Bu çalışmanin öğrencilerin matematiksel muhakeme becerilerine sahip olma düzeylerini belirlemede öğretmenlerin başvuracakları bir ölçme aracı hazırlamayarak onlara ve literatüre katkı sağlayacağı düşünülmektedir. 


\section{Yöntem}

\section{Çalışma Grubu}

Araştırmanın çalışma grubunu Manisa il merkezinde bulunan Milli Eğitim Bakanlığı'na bağlı bir ortaokulda öğrenim gören 7. Sinıflarda okuyan toplam 73 öğrenci oluşturmaktadır. Çalışma grubu araştırmaya gönüllü katılım gösteren öğrencilerden oluşmaktadır. Öğrencilerin 36'sı (\%49) erkek, 37'si (\%51) kadın öğrencilerden oluşmaktadır.

\section{Ölçme Aracı}

Araştırmada ortaokul altıncı sınıf öğrencilerin matematiksel muhakeme becerilerini değerlendirmek amacıyla bir ölçek geliştirilmiştir. Matematiksel muhakeme değerlendirme ölçeği, 11'i çoktan seçmeli, 12'si kısa cevaplı sorular olmak üzere iki kısımdan oluşmaktadır. Birinci kısım, matematiksel muhakemenin alt boyutlarından her birini ölçebilecek yeterli sayıda soru bulunabilmesi böylece kapsam geçerliğinin sağlanması amacıyla çoktan seçmeli sorulardan, ikinci kısım ise matematiksel düşünme süreçlerini, muhakeme becerilerini nasıl kullandıklarını açılamalarına firsat verecek sorulardan oluşmaktadır (Pilten, 2008).

\section{Ölçeğin Geliştirilme Aşaması}

Literatürdeki çalışmalar incelendiğinde ölçek geliştirmenin dört aşamadan oluştuğu görülmektedir (Erdem, 2015; Kalayc1, 2010; Karasar, 2009; Pilten, 2008). Bunlar;

- Madde havuzu

- Uzman görüşü (Kapsam Geçerliliğinin Sınanması aşaması)

- Ön uygulama

- Geçerlik güvenirlik çalışmaları

Çalışmada geliştirilen matematiksel muhakeme değerlendirme ölçeği geliştirilmesi aşamasında ise yukarıda verilen aşamaları da içinde barındıran Tracy ve Gibson (2005, s.40) tarafından belirtilen aşamalar uygulanmıştır. $\mathrm{Bu}$ aşamalar; 
1. aşama: Bu aşamada matematiksel muhakeme kavramının tanımlanması ve nasıl ölçüldüğünün belirlenmesi amacıyla literatür taraması yapılmiştır.

2. aşama: Bu aşamada ölçeğe ait maddeler geliştirilmiştir. Maddeler geliştirilirken sırası ile; cevap formatları belirlenmiştir, madde havuzu oluşturulmuştur, kapsam geçerliliği için uzman görüşlerine başvurulmuştur, maddeler tekrar gözden geçirilmiştir ve güvenirlik geçerlik çalışmaları için maddeler geniş bir örneklem üzerinde uygulanmıştır.

3. aşama: $\mathrm{Bu}$ aşamada veri analizler gerçekleştirilmiştir. Veri analizleri, madde istatistikleri belirlenerek, kapsam geçerliliği için uzman görüşleri alınarak (2 alan uzmanı, 2 eğitim bilimleri uzmanı) ve ölçeğin güvenirlik katsayısı hesaplanarak yapılmıştır.

\section{Matematiksel Muhakeme Kavramı ve Alt Boyutlarnın Belirlenmesi}

Literatürde muhakemenin değerlendirilmesi ile ilgili araştırmalar taranarak matematiksel muhakeme ölçeğinin alt boyutları oluşturulmuştur. Literatürde matematiksel muhakemenin değerlendirilmesine yönelik belirtilen boyutlar matematiksel muhakemeye ilişkin göstergeler kısaca şu şekildedir;

MEB (2013); muhakeme becerilerini akıl yürütme becerisi olarak ele almış ve gösterge davranışlarını şu şekilde ifade etmiştir;

- Çıkarımların doğruluğunu ve geçerliliğini savunma

- Mantıklı genellemelerde ve çıkarımlarda bulunma

- Bir matematiksel durumu analiz ederken matematiksel örüntü ve ilişkileri açıklama ve kullanma

- Yuvarlama, uygun sayıları gruplandırma, ilk veya son basamakları kullanma gibi stratejileri veya kendi geliştirdikleri stratejileri kullanarak işlem ve ölçümlerin sonucuna dair tahminlerde bulunma

- Belirli bir referans noktasını dikkate alarak ölçmeye ilişkin tahminde bulunma

NCTM (1989; 2000); muhakeme becerilerini, muhakeme, matematiksel güç ve problem çözme içerisinde ele almış ve gösterge davranışlarını şu şekilde ifade etmiştir;

- Matematiksel tahminleri mantığa uygun olarak oluşturma,

- Matematiksel tartışmaları geliştirme ve değerlendirme, 
- Toplanan veya ortaya konan bilgileri farklı yöntemlerle ve şekillerde sunma,

- Muhakeme yaparken tümevarımı ve tümdengelimi etkin olarak kullanma

- Düşündüklerini, varsayımlarını doğru olduklarını savunacak açılamalar yapma, gerekçeler sunma

TIMSS (2003;2011); muhakeme becerilerini problem çözme ve matematiksel muhakeme becerileri içerisinde ele almış ve kategorileri şu şekilde ortaya koymuştur;

- Analiz

- Genelleme

- Sentez

- Gerekçelendirme

- Rutin olmayan problemleri çözme

Çiftçi (2015); yaptığı araştırmada matematiksel muhakemenin alt boyutlarını şu şekilde ifade etmiştir;

- Uygun çıkarımlarda bulunma ve genellemeler yapma

- Varsayımların veya çıkarımların geçerliliğini savunma

- Matematiksel sembolleri ve kuralları kullanma

- Matematiksel ilişkileri kullanma

- Tahminlerde bulunma ve bunu mantığa uygun olarak gerekçelendirebilme

- Genel ilişkileri var olan özel durumlara uygulayabilme

- Matematiksel ispat sürecinde tümevarımı ve tümdengelimi uygun olarak kullanabilme

Pilten (2008); yaptığı araştırmasında matematiksel muhakemenin alt boyutlarını şu şekilde belirlemiştir;

- Uygun muhakemeyi belirleme ve kullanma

- Matematiksel bilgileri /örüntüleri / yapıları / genel özellikleri tanıma ve kullanma

- Aynı verinin farklı gösterimlerini tanıma

- Tahmin etme

- Çözüme ilişkin mantıklı tartışmalar geliştirme

- Çözüm yolu / sonucun doğruluğuna karar verme

- Genelleme yapma

- Rutin olmayan problemleri çözme 
- Sumarmo (2006) araştırmasında matematiksel muhakemeye ilişkin göstergeleri şu şekilde sıralamıştır (Akt: Kadarisma, vd., 2019).

- Mantıksal sonuçların çıkarılması

- Modellerle, gerçek durumlarla, sahip oldukları ilişkiler ve özelliklerle ilgili açıklamalar yapma

- Cevaplara ve çözüm süreçlerine ilişkin tahminlerde bulunma

- Matematiksel durumları analiz etmek için modellemeleri ve ilişkileri kullanma

- Hipotezler oluşturup gözden geçirme

- Geçerli gerekçeler üretme

- Doğrudan veya dolaylı matematiksel çıkarımların yapılması ve kullanilması

Yukarıda verilen araştırmalardan yola çıkarak matematiksel muhakeme becerilerine ilişkin belirtilen gösterge ve davranışlardan benzer olanların sınıflandırılması ve ortak olanların gruplandırılması sonucu aşağıda matematiksel muhakemenin alt boyutları şu şekilde kararlaştırılmıştır;

1. Tahmin etme

2. Aynı verinin farklı gösterimlerini tanıma

3. Örüntüleri tanıma

4. Çözüm yolunun ve sonucun doğruluğuna karar verme

5. Genelleme

6. Rutin olmayan problemleri çözme

7. Çözüm için mantıklı yollar geliştirme

\section{Madde Havuzunun Oluşturulması}

Literatür incelendiğinde öğrencilerin matematiksel muhakeme becerilerini ortaya koyan ölçek veya testlerin geliştirildiği görülmüştür (Akay, Soybaş ve Ergün, 2006; Erdem, 2015; Mandacı-Şahin 2007; NAEP, 2002; Pilten, 2008; TIMSS, 2003). Geliştirilen ölçeklerin veya testlerin çoktan seçmeli, kısa cevaplı veya açık uçlu maddelerden oluştuğu görülmektedir. Pilten (2008) geliştirdiği ölçekte 23 çoktan seçmeli, 18 açık uçlu madde kullanmıştır. NAEP (2002) ve TIMSS (2003) de aynı şekilde muhakeme becerilerini değerlendirirken çoktan seçmeli ve açık uçlu soruları kullanmışlardır. Çoban (2010) araştırmasında muhakeme becerilerini hem çoktan seçmeli hem de açık uçlu maddeleri kullanarak bir ölçek geliştirmiştir. Erdem (2015) muha- 
keme becerilerini ölçmek amacıyla 24 açık uçlu madde ile ölçme aracı geliştirmiştir. Erdem (2016) yaptığı bir başka araştırmasında ise 33 sorudan ve tamamı çoktan seçmeli maddelerden oluşan muhakeme ölçeğini geliştirmiştir.

Literatür taraması sonucunda bu araştırmada kapsam geçerliğini sağlamak amacıyla her boyuttan yeterli miktarda soru sorulmasını kolaylaştırmak için çoktan seçmeli sorularla birlikte öğrencilerin muhakemelerini ortaya koyacakları açı uçlu maddelerin birlikte kullanılmasına karar verilmiştir. Literatür incelemesine dayalı olarak oluşturulan ölçeğin alt boyutlarında yer alan çoktan seçmeli ve açlk uçlu maddelerden oluşan 37 madde hazırlanarak madde havuzu oluşturulmuştur.

\section{Ölçeğin Uygulanması ve Analiz Süreci}

37 maddelik hazırlanan taslak ölçeğin kapsam geçerliğini belirlemek için 2 eğitim programı uzmanı, 2 matematik eğitimi alanında uzman ve 2 matematik öğretmeninin görüşleri alınmıştır. Uzman görüşleri sonucunda kalan maddeler geçerlik, güvenirlik çalışmaları için 73 öğrenciye uygulanarak madde analizleri yapılmıştır (Beanland Schneider, LoBiondo-Wood ve Haber, 1999). Öğrencilerin sorulara verdiği cevaplar doğru ve yanlış olarak “0” ve "1" şeklinde kodlanarak ölçeğin KR-20 güvenirlik katsayısı hesaplanmıştır. Ayrıca Alt-Üst Grup \%27 tekniği ile madde ayırt edicilikleri ve madde güçlük indeksleri incelenmiştir (Kelley, 1939).

\section{Bulgular}

\section{Kapsam ve Görünüş̧ Geçerliliğinin Sınanması Aşaması}

Ölçme aracının kapsam ve görünüş geçerliliğinin sınanması için uzman görüşünün yanı sıra pilot uygulaması yapılmıştır. Tavşancıl (2005)' a göre geçerlik göre kapsam geçerliliği ölçme aracının ölçtüğü özelliğe dair uzman görüşüdür ve sayısal olarak ifade edilemez. Geçerlilik bir maddenin ölçmek istediği özelliği ne derece doğru ölçtüğüne ilişkin bir göstergedir. Kapsam geceliği için bir belirtke tablosu hazırlamak, hazırlanan belirtke tablosuna göre test maddelerini geliştirip bir ölçek taslak formu düzenlemek daha sonra da bu ölçek formunu incelemeleri için uzmanların görüşüne sunmak 
gerekmektedir (Polit ve Hungler 1999; Zeidner, 1989). Bir ölçme aracının kapsam geçerliği, ölçme aracının (testin) ölçülmek istenen özelliği ya da yapıyı yansıtması, bu yapıya uygunluğu ve ilgili olmasıdır (Lawshe, 1975; Messick, 1993).

Tablo 1. Taslak Ölçeğe Ait Belirtke Tablosu

\begin{tabular}{|c|c|c|c|c|c|c|c|c|}
\hline No & $\begin{array}{l}\text { Alt } \\
\text { boyut- } \\
\text { lar }\end{array}$ & $\begin{array}{l}\text { Tah } \\
\text { min } \\
\text { Etme }\end{array}$ & $\begin{array}{l}\text { Aynı Verinin } \\
\text { Farklı } \\
\text { Gösterimlerini } \\
\text { Tanıma }\end{array}$ & $\begin{array}{l}\text { Örüntüleri } \\
\text { Tanıma }\end{array}$ & $\begin{array}{l}\text { Çözüm } \\
\text { Yolunun } \\
\text { Ve Sonucun } \\
\text { Doğruluğuna } \\
\text { Karar Verme } \\
\end{array}$ & $\begin{array}{l}\text { Genelle- } \\
\text { me } \\
\text { Yapma }\end{array}$ & $\begin{array}{l}\text { Rutin } \\
\text { Olmayan } \\
\text { Problemleri } \\
\text { Çözme }\end{array}$ & $\begin{array}{l}\text { Çözüm İçin } \\
\text { Mantıklı } \\
\text { Yollar } \\
\text { Geliştirme }\end{array}$ \\
\hline 1 & & & & & & & & $\checkmark$ \\
\hline 2 & & & & & & & & $\checkmark$ \\
\hline 3 & & & & & & & & $\checkmark$ \\
\hline 4 & & $\checkmark$ & & & & & & $\checkmark$ \\
\hline 5 & & & & & & & & $\checkmark$ \\
\hline 6 & & & & & & & & $\checkmark$ \\
\hline 7 & & & & & & & $\checkmark$ & $\checkmark$ \\
\hline 8 & & & & & & & $\checkmark$ & $\checkmark$ \\
\hline 9 & & & & & & & & $\checkmark$ \\
\hline 10 & & & & & & $\checkmark$ & & \\
\hline 11 & & & & & & & $\checkmark$ & \\
\hline 12 & & & & & & & & $\checkmark$ \\
\hline 13 & & $\checkmark$ & & & & & $\checkmark$ & $\checkmark$ \\
\hline 14 & & & & & & & $\checkmark$ & $\checkmark$ \\
\hline 15 & & & & & & & & $\checkmark$ \\
\hline 16 & & & & & $\checkmark$ & & & \\
\hline 17 & & & & & & $\checkmark$ & & \\
\hline 18 & & & & & $\checkmark$ & & & \\
\hline 19 & & & $\checkmark$ & & & & & \\
\hline 20 & & & $\checkmark$ & & & & & \\
\hline 21 & & & $\checkmark$ & & & & & $\checkmark$ \\
\hline 22 & & & $\checkmark$ & & & & & \\
\hline 23 & & & $\checkmark$ & & & & & \\
\hline 24 & & $\checkmark$ & & & & & & \\
\hline 25 & & & & & & $\checkmark$ & & \\
\hline 26 & & $\checkmark$ & & & & & & \\
\hline 27 & & $\checkmark$ & & & & & & \\
\hline 28 & & & & $\checkmark$ & & & & \\
\hline 29 & & & & $\checkmark$ & & & & \\
\hline 30 & & & $\checkmark$ & & & & & \\
\hline 31 & & & & & $\checkmark$ & & & \\
\hline 32 & & & & & & $\checkmark$ & & $\checkmark$ \\
\hline 33 & & & $\checkmark$ & & & & & \\
\hline 34 & & & & & & & $\checkmark$ & \\
\hline 35 & & & $\checkmark$ & & & & & \\
\hline 36 & & & & & & & $\checkmark$ & \\
\hline 37 & & & & & & & $\checkmark$ & \\
\hline TOP. & & 5 & 8 & 2 & 3 & 4 & 8 & 15 \\
\hline
\end{tabular}


Hazırlanan 37 taslak soru 2 eğitim programı uzmanı, 2 matematik eğitimi alanında uzman ve 2 matematik öğretmeninin görüşlerine sunulmuştur. Bu sayede ölçeğin kapsam geçerliği ve görünüş geçerliği incelenmiştir (Haladyna, 1999; Nevo, 1985; Sireci ve Geisinger, 1995). Hazırlanan maddelerin yer aldıkları alt boyutlara ilişkin veriler Tablo-1 de sunulmuştur.

Tablo-1 incelendiğinde matematiksel muhakemenin 7 alt boyutunu içine alan toplam 37 madde bulunmaktadır. Maddelerden bazılarının birden fazla boyutun içerisinde yer aldığ görülmektedir. Maddelerin alt boyutlara dağılımı incelendiğinde, "tahmin etme" becerisine ilişkin alt boyutta 5 madde, "aynı veriye ait farklı gösterimleri tanıma" becerisine ilişkin alt boyutta 8 madde, "örüntüleri tanıma" becerisine ilişkin 2 madde, "çözüm yolunun veya sonucun doğruluğuna karar verme" becerisine ait alt boyutta 3 madde, "genelleme" becerisine ilişkin 4 madde, "rutin olmayan problemleri çözme" becerisine ait 8 madde ve "çözüme ilişkin mantıklı yollar geliştirme" becerisine ait alt boyutta 15 madde matematiksel muhakeme ölçeğinde yer almıştır.

Uzman görüşleri neticesinde "çözüm için mantıklı yollar geliştirme, aynı verinin farklı gösterimlerini tanıma ve rutin olmayan problemleri çözme boyutlarında yer alan maddelerin çok sayıda ve benzer yapıda olması ayrıca birbiri ile aynı davranış ve becerileri ölçmeleri" ve "aynı maddenin birden fazla boyutta yer almasının ölçme sürecinde sorun oluşturacağı" şeklindeki görüşlerle 13 madde testten çıkarılmıştır. Ayrıca "örüntüleri tanıma" alt boyutunda 2 madde olması yetersiz görülerek "çözüm için mantıklı yollar geliştirme" boyutundaki 1 maddenin yerine "örüntüleri tanıma" alt boyutuna 1 madde eklenmiştir. Son olarak kalan 24 madde ile güvenirlik ve geçerlilik çalışmalarına devam edilmiştir. Güvenirlik ve geçerlik çalışmaları için 24 maddelik ölçeğin yer aldığı alt boyutlara ilişkin veriler Tablo-2' de sunulmuştur.

Tablo-2 incelendiğinde matematiksel muhakemenin 7 alt boyutunu içine alan toplam 24 madde bulunmaktadır. Bu maddelerin alt boyutlara dağılımı incelendiğinde, "tahmin etme" becerisine ilişkin alt boyutta 3 madde, "aynı veriye ait farklı gösterimleri tanıma" becerisine ilişkin alt boyutta 3 madde, "örüntüleri tanıma" becerisine ilişkin 3 madde, "çözüm yolunun veya sonucun doğruluğuna karar verme" becerisine ait alt boyutta 3 madde, "genelleme" becerisine ilişkin 3 madde, "rutin olmayan problemleri çözme" becerisi- 
ne ait 3 madde ve "çözüme ilişkin mantıklı yollar geliştirme" becerisine ait alt boyutta 6 madde matematiksel muhakeme ölçeğinde yer almıştır.

Tablo 2. Güvenirlik-Geçerlik Çalışmalarnnda Kullanılan Ölçeğin Belirtke Tablosu

\begin{tabular}{|c|c|c|c|c|c|c|c|c|}
\hline $\begin{array}{l}\dot{z} \\
\text { D }\end{array}$ & 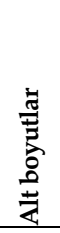 & 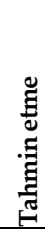 & 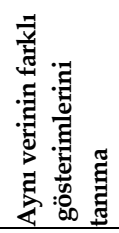 & 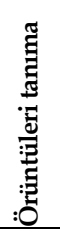 & 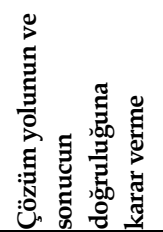 & 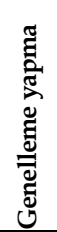 & 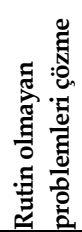 & 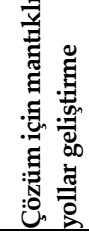 \\
\hline 1 & & $\checkmark$ & & & & & & \\
\hline 2 & & $\checkmark$ & & & & & & \\
\hline 3 & & & $\checkmark$ & & & & & \\
\hline 4 & & & $\checkmark$ & & & & & \\
\hline 5 & & & & $\checkmark$ & & & & \\
\hline 6 & & & & $\checkmark$ & & & & \\
\hline 7 & & & & & $\checkmark$ & & & \\
\hline 8 & & & & & $\checkmark$ & & & \\
\hline 9 & & & & & & $\checkmark$ & & \\
\hline 10 & & & & & & $\checkmark$ & & \\
\hline 11 & & & & & & & & $\checkmark$ \\
\hline 12 & & & & & & & & $\checkmark$ \\
\hline 13 & & $\checkmark$ & & & & & & \\
\hline 14 & & & $\checkmark$ & & & & & \\
\hline 15 & & & & $\checkmark$ & & & & \\
\hline 16 & & & & & $\checkmark$ & & & \\
\hline 17 & & & & & & $\checkmark$ & & \\
\hline 18 & & & & & & & $\checkmark$ & \\
\hline 19 & & & & & & & $\checkmark$ & \\
\hline 20 & & & & & & & $\checkmark$ & \\
\hline 21 & & & & & & & & $\checkmark$ \\
\hline 22 & & & & & & & & $\checkmark$ \\
\hline 23 & & & & & & & & $\checkmark$ \\
\hline 24 & & & & & & & & $\checkmark$ \\
\hline Top. & & 3 & 3 & 3 & 3 & 3 & 3 & 6 \\
\hline
\end{tabular}

Ölçeğin uygulama öncesinde yapılan bir diğer inceleme kapsam geçerliğinin bir alt türü olan görünüş ya da yüzey geçerliğidir (Beanland \& ark., 1999). Görünüş geçerliği ölçme aracının açıklık, okunabilirlik ve düzen gibi kolayca uygulanabilirlik özelliklerini içerir Messick, 1993). Ayrıca soruların açık, okunabilir olması, yazım imlan noktalama gibi hususlarla ilgili hataların olmamasıdır. Hem uzman görüşüne göre hem de yüz yüze pilot uygulama ile test edilebilmektedir (Haladyna, 1999). Bu çerçevede öncelikle alan 
uzmanlarına ve Türkçe öğretimi uzmanlarının görüşüne sunularak taslak formun dil, anlatım, üslup, yazım, imla ve noktalama açısından incelemeleri ve hata varsa bunların düzeltilmesi istenmiştir. Uzman dönütleri neticesinde her hangi bir düzeltme yapılmamıştır. Daha sonra ise 4 öğrenciye yüz yüze ve tek tek soruları okumaları ve cevaplamaları istenerek okunmayan, anlaşılmayan ifade, cümle, terim vb. olup olmadığı gözlenmiş ve kendilerine sorulmuştur. Pilot uygulamadan elde edilen dönütlerle her hangi bir düzeltme yapma gereksinimi ortaya çıkmamıştır.

\section{Madde Ayırt Ediciliği, Güçlü̆̆ü ve Test Madde Korelasyonu}

Bir testin madde güçlüğü ve ayırt ediciliği ve anahtar cevap kontrolü testin yapı geçerliği hakkında fikir verir (Haladyna 1999; Polit ve Hungler, 1999; Scherbaum, Cohen-Charash, ve Kern, 2006). Yapı geçerliği, bir testin ölçülmek istenen teorik özelliği ölçebilme yeterliliğidir (Tekin, 2000). Madde ayırt ediciliği, soruların bilen ile bilmeyeni ayırt etmesidir (Haladyna, 1999). Ayrıca madde ayırt ediciliği ölçme aracındaki her bir maddenin genel test performansı ile ilişkisini ifade eder (Linn ve Gronlund, 2000). Bir sorunun yüksek düzeyde ayırt edici olması, testin genelinden yüksek puan alanların, o soruyu doğru cevaplaması, soruyu yanlış cevaplayanların ise doğru cevaplayanlar kadar yüksek puan almamasıdır. Bir sorunun güçlügü ise, soruyu doğru cevaplayanların testi cevaplayanlara oranı ile ifade edilir (Gronlund, 1968; Tekin, 2000; Tezci, 2016). Testin ayırt ediciliğinde farklı yöntemler olmakla birlikte madde toplam korelasyonlarının incelenmesi üst grup alt grup \%27 tekniği ile incelemenin yapılması sıklıkla önerilir (Beanland ve ark., 1999; Tekin, 2000). Madde toplam korelasyonlarında nokta çift serili ve korelasyonu önerilir. 0.25 ve üstünde değer kabul edilebilir sınır olarak önerilmektedir (Beanland ve ark., 1999; Cohen ve Cohen, 1983). "Matematiksel Muhakeme Değerlendirme Ölçeği" ne ilişkin maddelerin ayırt edicilikleri ve güçlükleri Tablo 3 'te verilmiştir. 
Tablo 3. Matematiksel Muhakeme Ölçeğine Ait Madde Ayırt Edicilikleri ve Madde Güçlïkleri

\begin{tabular}{llll}
\hline Soru & Madde Güçlük & Madde Ayırt Edicilik & Madde Toplam Korelasyonu \\
\hline $\mathbf{1}$ & 0.18 & $-0.17^{*}$ & -.31 \\
$\mathbf{2}$ & 0.36 & 0.28 & .30 \\
$\mathbf{3}$ & 0.64 & 0.72 & .50 \\
$\mathbf{4}$ & 0.44 & 0.67 & .36 \\
$\mathbf{5}$ & 0.61 & 0.44 & .33 \\
$\mathbf{6}$ & 0.69 & 0.50 & .33 \\
$\mathbf{7}$ & 0.56 & 0.22 & .27 \\
$\mathbf{8}$ & 0.58 & 0.50 & .39 \\
$\mathbf{9}$ & 0.44 & 0.56 & .48 \\
$\mathbf{1 0}$ & 0.36 & 0.39 & .39 \\
$\mathbf{1 1}$ & 0.25 & 0.22 & .25 \\
$\mathbf{1 2}$ & 0.42 & 0.61 & .53 \\
$\mathbf{1 3}$ & 0.39 & 0.44 & .29 \\
$\mathbf{1 4}$ & 0.19 & 0.39 & .37 \\
$\mathbf{1 5}$ & 0.53 & 0.61 & .33 \\
$\mathbf{1 6}$ & 0.28 & 0.22 & .29 \\
$\mathbf{1 7}$ & 0.31 & 0.61 & .48 \\
$\mathbf{1 8}$ & 0.42 & 0.72 & .52 \\
$\mathbf{1 9}$ & 0.14 & 0.28 & .48 \\
$\mathbf{2 0}$ & 0.17 & 0.33 & .37 \\
$\mathbf{2 1}$ & 0.58 & 0.83 & .54 \\
$\mathbf{2 2}$ & 0.31 & 0.61 & .61 \\
$\mathbf{2 3}$ & 0.13 & 0.17 & .39 \\
$\mathbf{2 4}$ & 0.28 & 0.22 & .39 \\
\hline
\end{tabular}

* Testten çıkarılan madde

Bir testte yer alan maddelerden ölçülen özelliğe sahip olanlar ile sahip olmayanları iyi ayırt etmesi beklenir. Maddelerin ayırt ediciliğini ortaya koyan değere "madde ayırt edicilik indeksi" adı verilir ve madde ayırt edicilik indeksi madde geçerlilik katsayısı olarak da ifade edilir (Kutlu, 2008). Madde ayırt ediciliğinin testin geçerliliği ile yakından ilişkili olduğu ve madde ayırt ediciliklerinin yükseldikçe testin geçerliliğinin de artacağı ifade edilebilir. Tekin (2000) ve Towns (2014) 'e göre madde ayırt edicilik indeksi .20 ve üzerinde olan maddelerin ayırt edici maddeler olduğu söylenebilir. Tablo-4 incelendiğinde 1 . maddenin madde ayırt edicilik indeksinin negatif olduğu yani ölçülmek istenen özelliğe sahip olanla sahip olmayanı birbirinden ayırmada iyi olmadığı söylenebilir. Bu yüzden 1. madde testten çıkarılmıştır. Ayrıca 23 numaralı maddenin ayırt edicilik indeksi düşük olmakla birlikte düzeltilerek teste alınabileceğinden (Tezci, 2016; Towns, 2014) ölçek- 
ten çıarılmamıştır. Bu maddenin çeldiricilerinde düzeltme yaparak ölçeğe alınmasına karar verilmiştir. Diğer maddeler için madde ayırt ediciliklerinin iyi düzeyde olduğu söylenebilir.

Madde ayırt ediciliğinin bir göstergesi olan madde toplam korelasyonu (Haladyna, 1999; Nunnally ve Bernstein, 1994) incelenmiştir. Madde toplam korelasyonuna ilişkin yapılan nokta çift serili korelasyon analizi sonucunda 1. Maddenin negatif ( $r-31)$, diğer maddelerin pozitif anlamlı ilişkili olduğu gözlenmiştir. En yüksek ilişki 22. Madde ( $\mathrm{r}=.61)$, en düşük ilişki ise 11. Madde ( $\mathrm{r}=.25)$ ve bunu 7. Maddenin ( $\mathrm{r}=.27)$ izlediği belirlenmiştir. Tüm maddelerin birbiri ile korelasyonu incelendiğinde 1 . Madde dışında en düşük ilişki 2. Madde ile 22. Madde arasında ( $\mathrm{r}=.04, \mathrm{p}>.05)$, en yüksek ilişki ise 18 ile 25. Madde arasında $(\mathrm{r}=.53, \mathrm{p}<.05)$ olduğu belirlenmiştir.

Teste alınacak maddeler hakkında karar verirken bir diğer inceleme ise madde güçlügüudür. Testin genelinin güçlügünün orta düzeyde ancak bir testte kolay ve zor maddelerin bulunmasının yararlı olacağ 1 da belirtilmektedir (Tekin, 2000; Tezci, 2016). Bir test maddesinde doğru cevap verenlerin yüzdesini gösteren orana "madde güçlük indeksi" adı verilir. Bir maddenin madde güçlük indeksi 0 ile 1 aralığında değerler alır. Madde güçlük indeksinin aldığı değer 0.00 'a yaklaştıkça maddeyi doğru cevaplayanların oranının azaldığı dolayısıyla maddenin zorluğunun arttığı, 1.00' a yaklaştıkça maddeyi doğru cevaplayanların oranının arttığı dolayısıyla maddenin kolaylaştığı yorumu yapılabilir (Hattie, 1985; Towns, 2014). Kutlu (2008), uygun madde güçlügünün 0.30-0.69 olduğunu belirtmiştir. Tabloya bakıld1ğında maddelerin çoğunluğunun madde güçlük indekslerinin 0.30-0.69 arasında yer aldığı görülmektedir. Bu bakımdan testin orta zorluğa yakın olduğu söylenebilir.

Anahtar cevap kontrolü aşamasında ise anahtarlanmış doğru cevabın doğru cevap olup olmadığı ve seçenekler içinde birden fazla doğru cevap olup olmadığının incelenmesidir. Bunun için ayn içerik alanında çalışma yapan uzmanlardan görüş alınması ve konsensusun sağlanması önerilmektedir (Haladyna, 1999). Birden fazla doğru cevap olmadığı, anahtarlanmış doğru cevabın hata içermediği 4 uzman tarafından yapılan incelemede görüş birliği ile ifade edilmiştir. 


\section{Ölçeğin Güvenirliği}

Güvenirlik, belirli bir evrene veya örnekleme uygulanmış bir test ya da ölçme aracından elde edilmiş ölçümlerin tutarlılığı veya tekrarlanabilirliğidir (Bademci, 2011). Güvenirliğin hesaplanmasına ilişkin birçok yol mevcut olmakla birlikte bu çalışmada KR-20 Güvenirlik Katsayısı kullanılmıştır (Schroeder, Murphy, ve Holme, 2012; Tezci, 2016). 24 maddelik ölçek 7. Sınıfa devam eden 3 farklı şubede öğrenim gören 73 öğrenciye uygulanarak elde edilen veriler doğru yanlış olarak " 0 " ve " 1 " şeklinde kodlanmış ve madde analizleri ve güvenirlik, geçerlik çalışmaları yapılmıştır. Ölçümlerin güvenirliğini ortaya koyan KR-20 güvenirlik katsayısı bu araştırmada 0.81 olarak hesaplanmıştır. Hesaplanan bu değer matematiksel muhakeme değerlendirme ölçeğinden elde edilen ölçümlerin iyi derecede güvenirliğe sahip olduğunu göstermektedir.

Matematiksel muhakeme değerlendirme ölçeğine son hali verildikten sonra matematiksel muhakemeye ait 7 alt boyutta toplam 23 madde yer almaktadır. Testte yer alan maddelere ve boyutlara ilişkin bilgiler Tablo-4' de verilmiştir.

Tablo-4 incelendiğinde matematiksel muhakemenin 7 alt boyutunu içine alan toplam 23 madde bulunmaktadır. Bu maddelerin alt boyutlara dağılımı incelendiğinde, öğrencilerin işlem veya ölçüm yapmadan sonuçların ve ölçülerin yaklaşık değerlerini "tahmin etme" becerisine ilişkin alt boyutta 2 madde bulunmaktadır. Mevcut ilişkiler hakkında düşünüp çıkarımlar yapma ve çıkarımları test etme, fikirlerin sebeplerini araştırma ve sebepleri izah etme etkinliklerini kapsayan "çözüme ilişkin mantıklı yollar geliştirme" becerisine ait alt boyutta 6 madde yer alırken matematiksel bilgiler farklı şekillerde karşımıza çıtığında "aynı veriye ait farklı gösterimleri tanıma" becerisine ilişkin alt boyutta 3 madde bulunmaktadır. Belli bir kurala bağlı olarak devam eden sayı ve şekillerin ilişkilerini tanımaya yönelik "örüntüleri tanıma" becerisine ilişkin 3 madde mevcutken sonucun tahminine ilişkin yollar geliştirerek sonucun mantıklı olup olmadığına yani "çözüm yolunun veya sonucun doğruluğuna karar verme" becerisine ait alt boyuta 3 madde yer almaktadır. Problem çözme veya düşünme yoluyla elde edilen sonuçları daha geniş alana uygulanabilir şekilde ifade ederek "genelleme" yapma becerisine ilişkin 3 madde bulunurken farklı düşünmeye ve uygulamalara iten rutin problemler gibi çözüm yolları belli kalıplara sığmayan "rutin ol- 
mayan problemleri çözme" becerisine ait 3 madde matematiksel muhakeme ölçeğinde yer almıştır.

Tablo 4. Matematiksel Muhakeme Becerilerini Değerlendirme Ölçeğine ait alt boyutlar ve maddelere ilişkin belirtke tablosu

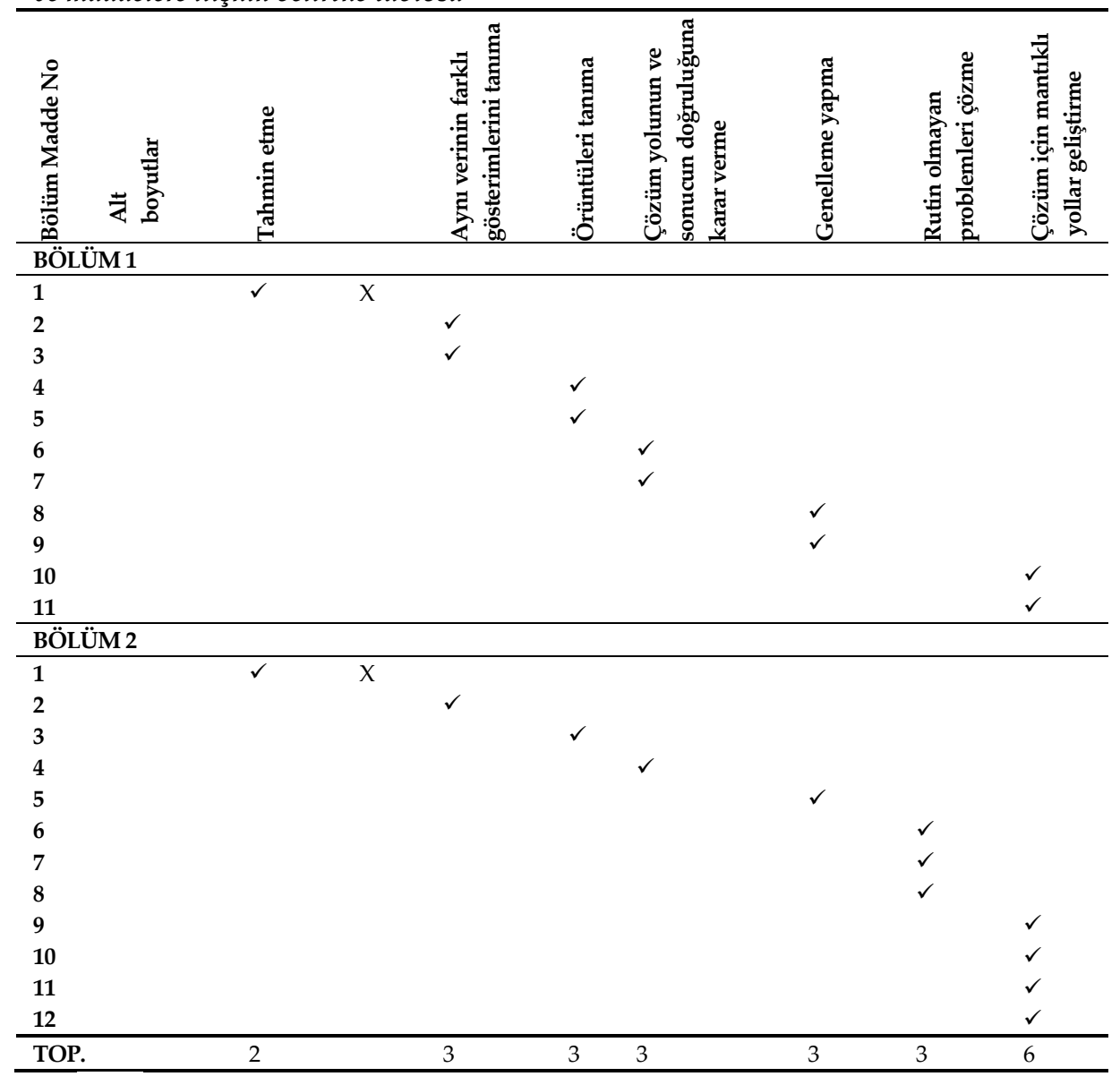

\section{Sonuç, Tartışma ve Öneriler}

Bu çalışmada ortaokul öğrencilerinin matematiksel muhakeme yeteneklerini ölçmede kullanılacak güvenilir ve geçerli bir testin geliştirilmesi amaçlanmıştır. Matematiksel muhakeme konusunda uluslararası literatürde hatırı sayılır düzeyde çalışma (Örnek: ACER, 2017; Indriati, 2018, Kaur ve Lam, 
2012) mevcut olmakla birlikte Türkçe literatürde hemen hemen yok denecek kadar azdır. Bu çerçevede ölçeğin, matematik öğretimi ve eğitim bilimleri alanında çalışma yapacaklara ve ortaokul öğretmenlerine ve ortaokul matematik öğretmeni yetiştiren kurumlardaki öğretim elemanlarına katkı sağlayacağı düşünülmüştür. Bu çerçevede ölçme aracının geliştirilmesi için öncelikle literatür taraması yapılmış, ortaokul matematik program incelenmiş ve matematiksel muhakemenin 7 alt boyutu belirlenmiştir. Matematiksel muhakemenin belirlenen yedi alt boyutuna dayalı olarak hazırlanan belirtke tablosundan yola çıkarak madde havuzu oluşturulmuştur. Her bir alt boyutun birden fazla soru hazırlanmıştır. Bu çerçevede 37 maddelik bir madde havuzu oluşturulmuştur. Alan uzmanları tarafından yapılan inceleme sonucunda birbiriyle binişik halde olan ve ayn özelliğin ölçüldüğü konusunda fikir birliğine ulaşılan 13 madde taslak formadan çıkarılmış ve 24 maddelik deneme formu hazırlanmıştır. Deneme formunun 1. bölümü 4 seçenekli 12 çoktan seçmeli test maddesinden oluşmaktadır. 2. bölüm ise 12 kısa cevaplı test maddesi niteliğindedir. Deneme formu öncelikle alan uzmanı, ölçme ve değerlendirme uzmanlarının incelemesine sunularak görünüş geçerliği incelenmiştir. Bu inceleme sonucunda ölçme aracında her hangi bir düzeltmeye gidilmemiştir. Deneme formu 4 ortaokul öğrencisine tek tek yüz yüze uygulanarak ölçme aracinda anlaşılmayan, okunmayan cümle, ifade olup olmadığı belirlenmiştir. Öğrencilerden yüz yüze yapılan cevaplama neticesinde anlaşılmayan cümle ya da ifadeye rastlanmamıştır. Bu süreçte ölçme aracına ayrılacak ortalama cevaplama süresi de tespit edilmiştir. Ölçme aracının anahtarlanmış doğru cevabı çıkarılmış ve alan uzmanlarından ölçme aracındaki soruları cevaplamaları istenmiştir. Her bir uzmanın doğru cevabı ile anahtarlanmış doğru cevap karşılaştırılmıştır. Bu inceleme ile anahtarlanmış doğru cevabın hataları içerip içermediği, doğru cevabın birden fazla olup olmadığı ve sorunun doğru cevabının olup olmadığı incelenmiştir. Her bir uzmanın cevapları ile anahtarlanmış cevap arasinda ve uzmanların cevapları arasında \%100'lük uyum belirlenmiştir.

Ölçme aracı 73 ortaokul 7. sınıf öğrencisine uygulanmıştır. Uygulama sonucunda elde edilen veriler öncelikle her bir maddenin madde ayırt edicilik indeksi hesaplanmıştır. 1. sorunun madde ayırt edicilik indeksi negatif olduğundan ölçekten çıkarılmıştır. 23 numaralı sorunun ayırt ediciliği 0.17 olmakla birlikte seçeneklerinde düzeltme yaparak teste alınmasına karar verilmiştir. Testteki soruların güçlük düzeyleri incelendiğinde ise kolay orta 
zor ve çok zor soruların bulunduğu gözlenmiştir. Bununla birlikte testin genelinin 1. soru hariç orta güçlük düzeyine $(\mathrm{p}=.40)$ yakın olduğu gözlenmiştir. Test madde korelasyonu incelendiğinde ise 1 . sorunun negatif diğer tüm soruların .25 üstünde olduğu belirlenmiştir. Madde analizi ve anahtarlanmış cevabı ilişkin yapılan incelemeler, testin geçerliği açısından yeterli olarak kabul edilmiştir.

Ölçme aracının güvenirliği belirlemek için 73 öğrenciden elde edilen veriler kullanılarak Kuder Richardson-20 formülü ile analiz edilmiştir. Güvenirlik analizi 1. madde ölçekten çıkarıldığından 23 madde için yapılmıştır. KR-20 güvenirlik katsayısı kalan 23 madde için 0.81 olarak hesaplanmıştır. $\mathrm{Bu}$ değer matematiksel muhakeme değerlendirme ölçeğinden elde edilen ölçümlerin iyi derecede güvenirliğe sahip olduğunu göstermektedir.

Çalışmada geliştirilen matematiksel muhakeme değerlendirme ölçeği, öğrencilerin akıl yürütme becerilerini ortaya koymak amacıyla oluşturulmuştur. Ölçek random (rastgele) olarak seçilen bir örnekleme uygulanmıştır. Uygulama neticesinde ölçeğin uygulanabilir olması açısından bir sorun görülmemiştir. Matematiksel muhakemenin 7 alt boyutunda yer alan 23 maddeden oluşan ölçeğin uygulanma aşamasında 40 dakikalık süre verilmiştir.

Matematiksel muhakeme değerlendirme ölçeğinin alt boyutları "tahmin etme", "çözüme ilişkin mantıklı yollar geliştirme", "aynı veriye ait farklı gösterimleri tanıma", "örüntüleri tanıma", "çözüm yolunun veya sonucun doğruluğuna karar verme", "genelleme" ve "rutin olmayan problemleri çözme" olarak belirlenmiş ve buna göre sorular oluşturulmuştur (EK-1). Çalışmanın sonucunda elde edilen ölçme aracı ile ortaokul öğrencilerin matematiksel muhakeme becerilerinin gelişip gelişmediği hakkında güvenilir ve geçerli olarak karar vermek mümkündür. Bu çalışmada ölçme aracının ölçüt geçerliğinin türlerinden olan yordama ya da uyum geçerliği hakkında bir inceleme yapılamamıştır. Ayrıca pilot uygulamada öğrenci sayısı sınırlı kalmıştır. Ölçeğin hem daha geniş örneklemlerde hem de ölçüt geçerliğinin incelenmesinin yararlı olacağı söylenebilir.

Matematiksel muhakeme becerilerinin özellikle matematiksel düşünme açısından önemli bir bileşen olduğu (Ginsburg, 1983) göz önüne alındığından bu becerilerin öğrencilerde gelişip gelişmediğinin de gözlenmesi o derecede önemlidir (Stiff ve Curcio, 1999). Stein, Grover ve Henningsen (1996), sınıfların, öğrencilerin matematiksel fikirleri ve çözümleri birbiri ile tartışmaya teşvik edildiği ve öğrencilerin fikirlerini ve çözümlerini oluşturacakla- 
rı kadar yeterli zamanın verildiği bir ortam olması gerektiğine dikkat çekmiştir. Özellikle matematiksel muhakeme yeteneklerinin gelişimi açısından, öğrencilerin eylemleri, ne yapması gerektiği, nasıl yapılacağı hakkında kararlar almalarını ve çözümlerinin makul olup olmadığı hakkında yorumda bulunmalarına imkan sağlayacak bir takım matematiksel görevlereproblemlere dikkatlerinin yoğunlaştırılmasının önemini vurgulamışlardır. Bu çerçevede de matematiksel muhakeme yeteneğinin bu araştırmada olduğu gibi tahmin etme, genelleme yapma, rutin olmayan problemleri çözme, çözüm için yollar geliştirme, çözümün doğruluğunu test etme, verinin farklı formlarda gösterimini yapma gibi yeterlilikleri kapsadığı (NTCM, 1999, 2000) ve özellikle matematiksel yeterlilikler açısından sinffta buna dayalı etkinliklerin yapılmasının önerildiği gözlenmektedir (Dreyfus ve Eisenberg, 1996). Kramarski, ve Mevarech, (2003), yaptıkları çalışmanın sonucunda matematiksel muhakeme açısından öğrencilere sunulacak problemlerin çözümlerinin yazılı veya açılamalara dayalı yapmalarını önermiştir. Bu ölçek geliştirme çalışmasında da öğrencilerden testin ikinci bölümünde cevapların yazarak belirtmeleri gerekmektedir. Ayrıca fikirlerde akıcılığın ve esnekliğin sağlanması için çeşitli sorulara ya da etkinliklere yer verilmesi önerilmektedirler. Bununla beraber fikirlerini haklı gösterecek çeşitli argümanlar geliştirmeleri de önerilmektedir. Ancak mevcut ölçekte öğrencilerin kendilerinden neden bu yönde bir cevap verdiğine dair bir açıklama istenmemiştir. Bir başka yönüyle incelendiğinde literatürde yapılan araştırmalarda (Baundonck, ve ark., 2006; Bridgeman, Harvey, ve Braswell, 1995; College Boar, 1992; Desoete, 2008; Lehman ve Mazzeo, 1991; Mevarech ve Kramarski, 2003) geliştirilen ya da kullanılan ölçme araçlarında da bu çalışmada olduğu gibi hem geleneksel çoktan seçmeli test maddelerini ihtiva eden hem de öğrencilerin cevap yazmalarını gerektiren sorulara yer verilmiştir. Bununla birlikte bu araştırmaların bazılarında öğrencilerden açıklama yazmalarını da gerektirecek nitel sorulara yer verildiği de görülmüştür.

Bu çalışmadan elde edilen sonuçlar, matematiksel düşünme becerilerinin ölçülmesinde kullanılacak ölçme araçlarında daha fazla çeşitte soruya yer verilmesi ve öğrencilerden beklenen cevaplarının hem yazılı hem açıklamalı hem de geleneksel tarzda olmasının yararlı olacağını göstermektedir. Ölçme aracının farklı ölçeklerden elde edilen puanlarla karşılaştırılmasının yararlı olacağı söylenebilir. 


\section{EXTENDED ABSTRACT}

\section{Developing The Mathematical Reasoning Skills Assessment Scale \\ Halil Çoban - Erdoğan Tezci \\ Ministry of Nation Education, Balıkesir University}

Reasoning can be expressed as a process of reaching a logical conclusion by reasoning and considering all the factors by making comparisons and generalizations based on the existing information (Altıparmak and Öziş, 2005; Erdem, 2011; Lithner, 2006; MEB, 2013; Umay, 2003). In this respect, the reasoning skill as the most needed basic skill to develop general mathematical skills is very important for the development of mathematical thinking and understanding and structuring of newly acquired mathematical knowledge (Ball and Bass, 2003; Herman et al., 2018). In mathematics, reasoning is one of the most commonly used skills. In this context, it can be stated that mathematical reasoning forms the basis of mathematics (Pilten, 2008; Herman et al., 2018).

Mathematical reasoning is the ability of individuals to approach the situations they encounter from a mathematical point of view, to investigate the cause and effect and to make sense of the situation and to make a logical conclusion by using mathematical concepts and symbols (Brodie, 2010; Erdem, 2015; MEB, 2013). Mathematical reasoning includes skills such as justification, generalization, communication, representation and symbolizing, which will enable learners to attain mathematical competence (Ball ve Bass, 2003; Brodie, 2010). Mathematical reasoning is expressed as a tool and an important skill in understanding mathematical concepts, generating mathematical ideas, structuring the new acquired knowledge, using mathematical applications in an effective and flexible way (Brodie, 2010; Ev-Çimen, 2008).

The aim of the study is to develop a scale to evaluate the mathematical reasoning skills of middle school students. Mathematical Reasoning Skills Assessment Scale aims to determine the level of students' mathematical reasoning skills. The study group consisted of a total of 73 students attending 7th grade in a middle school affiliated to the Ministry of National Edu- 
cation in the city center of Manisa. When the literature is examined, it is seen that the scale development studies are carried out in 4 stages: item pooling, expert opinion, pre-application and validity-reliability studies. In this research, the stages mentioned by Tracy and Gibson (2005, p.40), which includes 4 stages, were used.

As a result of the classification and grouping of similar ones among the indicators and behaviors mentioned in the literature about mathematical reasoning skills, sub-dimensions of mathematical reasoning "guessing", "recognizing different representations of the same data", "recognizing patterns", "deciding the correctness of the path and result"," generalizing", "solving non-routine problems", "developing logical ways to solve" as agreed.

When the scales or tests developed to evaluate mathematical reasoning skills are examined, it is seen that multiple choice, short-answer and openended items are used. In this study, in order to ensure the content validity in order to make it easier to ask enough questions from each dimension and in order to provide the students' reasoning it was decided to use multiple choice questions together with open-ended items. 37 items consisting of multiple choice and open-ended items in the sub-dimensions of the scale, which was formed based on the literature review, were prepared and item pool was created.

Expert opinions were taken to determine the scope validity of the 37 item trial scale. As a result of the expert opinions, a trial form was formed with 24 items agreed upon. Part 1 of the trial form consists of 12 multiplechoice test items with 4 options. The second part consists of 12 shortresponse test items. The trial form was firstly presented to the subject matter expert, measurement and evaluation experts and the validity of the scale was examined. As a result of this examination, no corrections were made in the measurement tool. The trial form was applied to 4 middle school students individually and it was determined whether there were unreadable sentences or expressions in the measurement tool. As a result of face-to-face responses from students, no sentence or expression was found. In this process, the average response time to be allocated to the measurement tool was also determined.

The instrument was piloted with 73 students and validity and reliability studies of the scale were conducted (Beanland, Schneider, LoBiondo- 
Wood, ve Haber, 1999). The students gave answers to questions of right and wrong as "0" and " 1 " encoded and KR-20 reliability coefficient of the scale was calculated. In addition, item analyze indexes were examined with $27 \%$ of High-Low group technique (Kelley, 1939). Item 1 was excluded from the scale because the item distinguishing index was negative. Although the distinguished of item 23 was 0.17 , it was decided to take the test by correcting its options. When the difficulty levels of the questions were examined, it was observed that there were easy, medium and very difficult questions. However, it was observed that the overall test was close to the medium difficulty level (p .40) except for question 1 . When the test item correlation was examined, it was found that the first question was negative all other questions above. The analysis of the substance analysis and the keyed response was considered sufficient for the validity of the test.

In order to determine the reliability of the instrument, the data obtained from 73 students were analyzed by Kuder Richardson-20. The reliability analysis was performed for 23 items since item 1 was excluded from the scale. The KR-20 reliability coefficient was 0.81 for the remaining 23 items. This value shows that the measurements obtained from the mathematical reasoning assessment scale have good reliability.

The scale, which is presented as a result of the study, consists of 23 items including 7 sub-dimensions of mathematical reasoning. As a result, "Mathematical Reasoning Skills Assessment Scale" was found to be valid and reliable. It is possible to make a reliable and valid decision about whether mathematical reasoning skills of middle school students are developed with the assessment tool.

\section{Kaynakça / References}

Abazaoğlu, İ., Yıldızhan, Y. ve Yıldırım, O. (2014). TIMSS 2011 Türkiye 8. sınıf fen bilimleri sonuçlarının değerlendirilmesi. Ĕğitim ve Öğretim Araştırmaları Dergisi. Journal of Research in Education and Teaching, 3(1), 278-288.

ACER (2017). The tests higher ability selection 13 Nisan 2016 tarihinde http:// www.acer.org/hast-secondary/thetests adresinden erişilmiştir. 
Akay, H., Soybaş, D. ve Argün, Z. (2006). Problem kurma deneyimleri ve matematik öğretiminde açık-uçlu soruların kullanımı. Kastamonu Eğitim Dergisi, 14(1), 129-146.

Altıparmak, K. ve Öziş, T. (2005). Matematiksel ispat ve matematiksel muhakemenin gelişimi üzerine bir inceleme. Ege Ĕ̆itim Dergisi, 6(1), 25-37.

Bademci, V. (2011). Kuder-Richardson 20, Cronbach'in alfası, Hoyt'un varyans analizi, genellenirlik kuramı ve ölçüm güvenirliği üzerine bir çalışma. Dicle Üniversitesi Ziya Gökalp Eğitim Fakültesi Dergisi, 17, 173-193.

Ball, D. L., ve Bass, H. (2003). Making mathematics reasonable in school. In (J. Kilpatrick, W. G. Martin, ve D. Schifter Ed.) A Research companion to principles and standards for school mathematics. İçinde (s.27-44). Reston, VA: National Council of Teachers of Mathematics.

Baudonck, M., Debusschere, A., Dewulf, B., Samyn, F., Vercaemst, V., ve Desoete, A. (2006). De Kortrijkse rekentest revision KRT-R. [The Kortrijk arithmetic test revision KRT-R]. Kortrijk: CAR Overleie.

Beanland, C., Schneider, Z., LoBiondo-Wood, G., ve Haber, J. (1999). Nursing research: Methods, critical appraisal and utilization. Mosby, Sydney, Australia:Harcourt Brace \& Company.

Bridgeman, B., Harvey, A., ve Braswell, J. (1995). Effects of calculator use on scores on a test of mathematical reasoning. Journal of Educational Measurement, 32(4), 323-340.

Brodie, K. (2010). Teaching mathematical reasoning in secondary school classrooms. London: Springer.

College Board. (1992). The new SAT. New York: Author.

Çiftçi Z. (2015). Ortaöğretim matematik öğretmeni adaylarmın matematiksel muhakeme becerilerinin incelenmesi. Yayınlanmamıs Doktora Tezi. Atatürk Üniversitesi, Eğitim Bilimleri Enstitüsü, Erzurum.

Çoban, H. (2010). Öğretmen adaylarının matematiksel muhakeme becerileri ile bilişötesi öğrenme stratejilerini kullanma düzeyleri arasındaki ilişki. Yayınlanmamış Yüksek Lisans Tezi, Gaziosmanpaşa Üniversitesi, Sosyal Bilimler Enstitüsü, Tokat.

Demir, G. ve Akar-Vural, R. (2016). Ortaöğretim matematik programının hedeflediği matematiksel yeterlilik ve becerilerinin kazandırılma sürecinin öğretmen görüşleri temelinde incelenmesi. Adnan Menderes Üniversitesi, Sosyal Bilimler Enstitüsü Dergisi 4(1), 118-139. 
Desoete, A. (2008). Multi-method assessment of metacognitive skills in elementary school children: How you test is what you get. Metacognition and Learning, 3(3), 189-206.

Dreyfus, T., ve Eisenberg, T. (1996). On different facets of mathematical thinking. In (R. J. Stermberg ve T. Ben-Zeev Eds.), The Nature of Mathematical Thinking içinde (s.253-284). Mahwah, NJ: Lawrence Erlbaum.

Erdem, E. (2011). Illköğretim 7. sinıf öğrencilerinin matematiksel ve olasiliksal muhakeme becerilerinin incelenmesi. Yayınlanmamış Yüksek Lisans Tezi, Adıyaman Üniversitesi, Fen Bilimleri Enstitüsü, Adıyaman.

Erdem, E. (2015). Matematiksel muhakemeyi geliştirmeye yönelik tasarlanan öğrenme ortamının etkileri. Yayınlanmamış Doktora tezi. Atatürk Üniversitesi Eğitim Bilimleri Enstitüsü, Erzurum.

Erdem, E. (2016). Matematiksel muhakeme ile okuduğunu anlama arasındaki ilişki: 8. sınıf örneği. Necatibey Eğitim Fakültesi Elektronik Fen ve Matematik Ĕ̆itimi Dergisi (EFMED) 10(1), 393-414.

Ev-Çimen, E. (2008). Matematik öğretiminde, bireye matematiksel güç kazandırmaya yönelik ortam tasarımı ve buna uygun öğretmen etkinlikleri geliştirilmesi. Yayınlanmamış Doktora Tezi. Dokuz Eylül Üniversitesi, Eğitim Bilimleri Enstitüsü, İzmir.

Ginsburg, H. P. (Ed.). (1983). The development of mathematical thinking. New York: Academic Press.

Gronlund, N. (1968). Constructing achievement tests. Prentice Hall, New Jersey Günhan, B. (2014). A case study on the investigation of reasoning skills in geometry. South African Journal of Education, 34. 1-19. 10.15700/201412071156.

Haladyna, T. M. (1999). Developing and validating multiple-choice test items.Lawrence Erlbaum, New Jersey.

Hattie J. (1986). Methodology review: Assessing unidimensionality of tests and items. Appl Psychol Meas, 9, 139-64.

Herman, T., (2018). Analysis of students' mathematical reasoning. In Journal of Physics: Conference Series 948(1), 2-3.

Indriati, D. (2018). Profile of mathematical reasoning ability of 8th grade students seen from communicational ability, basic skills, connection, and logical thinking. Journal of Physics: Conference Series, 1008(1), 1278. IOP Publishing. doi :10.1088/1742-6596/1008/1/012078 
Kadarisma, G., Nurjaman, A., Sari, I. P., ve Amelia, R. (2019). Gender and mathematical reasoning ability. In Journal of Physics: Conference Series, 1157(4), 2-3.

Kalaycı, Ş. (2010). SPSS uygulamalı çok değişkenli istatistik teknikleri (5. Baskı). Ankara: Asil Yayın.

Karasar, N. (2009). Bilimsel araştırma yöntemi (19. Baskı). Ankara: Nobel Yayın.

Kaur, B. ve Lam, T. (2012). Reasoning, communication and connections in mathematics.Singapore: World Scientific Publishing Co. Pte. Ltd.

Kelley, T. L. (1939). The selection of upper and lower groups for the validation of test items. J. Educ. Psychol, 30, 17-24.

Kilpatrick, J., Swafford, J., ve Findell, B. (2001). Adding it up: Helping children learn mathematics. Washington, DC: National Academy Press.

Kramarski, B., ve Mevarech, Z. R. (2003). Enhancing mathematical reasoning in the classroom: The effects of cooperative learning and metacognitive training. American Educational Research Journal, 40(1), 281-310.

Kutlu, O. (2008). Madde ve test istatistikleri. (G. Başol Ed.). Eğitimde Ölçme ve Değerlendirme içinde (s.138-151). İstanbul: Lisans Yayınevi.

Lawshe, C. H. (1975). A quantitative approach to content validity. Personnel Psychology, 28, 563-575.

Lehman, J. D., ve Mazzeo, J. (1991). Confirmatory factor analyses of mathematical prototypes. Paper presented at the Annual Meeting of the National Council on Measurement in Education, April, Chicago.

Linn, R. ve Gronlund, N. (2000). Measurement and assessment in teaching. New Jersey: Prentice Hall.

Lithner, J. (2006). A framework for analysing creative and imitative mathematical reasoning. $\quad 08 / 07 / 2017 \quad$ tarihinde http://citeseerx.ist.psu.edu/viewdoc/download?doi=10.1.1.466.7119\& $\underline{\text { rep}=r e p 1 \& t y p e}=p d f$ adresinden erişilmiştir.

Mandacı-Şahin, S. (2007). 8. Sınıf öğrencilerinin matematik gücünün belirlenmesi. Yayınlanmamış Doktora Tezi. Karadeniz Teknik Üniversitesi, Fen Bilimleri Enstitüsü, Trabzon.

M.E.B. (2013). Ortaokul matematik dersi öğretim programı. Ankara. 2 Mayıs 2017 tarihinde $\quad$ http://mufredat.meb.gov.tr/Dosyalar/201813017165445MATEMATIK\%20ÖĞRETIM\%20PROGRAMI\%202018v.pdf adresinden erişilmiştir.

M.E.B. (2017). Öğretmenlik mesleği genel yeterlilikleri. Ankara: Devlet Kitapları Müdürlüğü. 
Messick, S. (1993). Validity. (R.L. Linn Ed.), Educational measurement (3rd ed.) içinde (s.13- 103). Phoenix: American Council on Education/Macmillan Publishing.

NAEP. (2002). Mathematics framezork for the 2003 national assessment of educational progress. Washington, DC: National Assessment Governing Board.

NCTM. (1989). Curriculum and evaluation standards for school mathematics. Erişim: 10/03/2017 tarihinde https://docs.lib.purdue.edu/cgi/viewcontent.cgi?article=1453\&contex $\mathrm{t}=$ eandc adresinden erişilmiştir.

NCTM. (2000). Principles and standards for school mathematics. S. 64. 10/03/2017 tarihinde

https://www.nctm.org/uploadedFiles/Standards and Positions/PSS M ExecutiveSummary.pdf adresinden erişilmiştir.

Nevo, B. (1985). Face validation revisited. Journal of Educational Measurement, 22, 289-393.

Nunnally J. ve Bernstein, I. (1994). Psychometric theory. New York:McGraw Hill, Pilten, P. (2008). Üst biliş stratejileri öğretiminin ilköğretim beşinci sınıföğrencilerinin matematiksel muhakeme becerilerine etkisi. Yayınlanmamış Doktora Tezi. Gazi Üniversitesi, Eğitim Bilimleri Enstitüsü, Ankara.

Polit, D. F, ve Hungler, B. P (1999). Nursing research: Principles and methods. Lippincott Williams \& Wilkins, Philadelphia.

Scherbaum, C. A., Cohen-Charash, Y., ve Kern, M. J. (2006). Measuring general self-efficacy: A comparison of three measures using item response theory. Educational and Psychological Measurement, 66(6), 1047-1063.

Schroeder, J., Murphy, K., ve Holme, T. A. (2012). Investigating factors that influence item performance on ACS exams. J. Chem. Educ., 89, 346-350.

Sireci, S.G., ve Geisinger, K. F. (1995). Using subject-matter experts to assess content representation: An MDS analysis. Applied Psychological Measurement, 19(3), 241-255.

Stein, M. K., Grover, B. W., ve Henningsen, M. (1996). Building student capacity for mathematical thinking and reasoning: An analysis of mathematical tasks used in reform classrooms. American Educational Research Journal, 33(2), 455-488.

Stiff, L. V., ve Curcio, F. R. (1999). Developing Mathematical Reasoning in Grades K-12. 1999 Yearbook. Reston, VA: National Council of Teachers of Mathematics, ERIC 
Tavşancl, E. (2005). Tutumların ölçülmesi ve spss ile veri analizi.Ankara:Nobel Yayın. Tekin H. (2000). Eğitimde ölçme ve değerlendirme. Ankara: Yarg1 Yayın.

Temizöz, Y. (2013). İlköğretim ve ortaöğretim öğrencilerinin matematiksel problem çözme sürecinde kavramlar ile ilgili anlayışlarının ve kavram-işlem kullanımlarının rolü. Yayınlanmış Doktora Tezi. Gazi Üniversitesi Eğitim Bilimleri Enstitüsü, Ankara.

Tezci, E. (2016). Eğitimde ölçme ve değerlendirme. Ankara: Detay Yayın.

TIMSS, (2003). IEA's TIMSS 2003 international report on achievement in the mathematics cognitive domains: Findings from a developmental project international association for the evaluation of educational achievement. TIMSS \& PIRLS International Study Lynch School of Education, Boston College.

Towns, M. H. (2014). Guide to developing high-quality, reliable, and valid multiple-choice assessments. Journal of Chemical Education, 91(9), 1426-1431.

Tracy, L. ve Gibson, B. A. (2005). Development of an instrument to assess student attitudes toward educational process in an undergraduate core curriculum. Unpublished PhD Thesis, Univercity of Arkansas, USA.

Umay, A. (2003). Matematiksel muhakeme yeteneği. Hacettepe Üniversitesi, Eğitim Fakültesi Dergisi, 24, 234-243.

Zeidner, M. (1989). Essay versus multiple choice type classroom examinations: The students perspective. Journal of Educational Research, 80, 352-358.

EK 1. Matematik Muhakeme Ölçeği MATEMATIKSEL MUHAKEME DEĞERLENDIRME ÖLÇEĞİ BÖLÜM 1

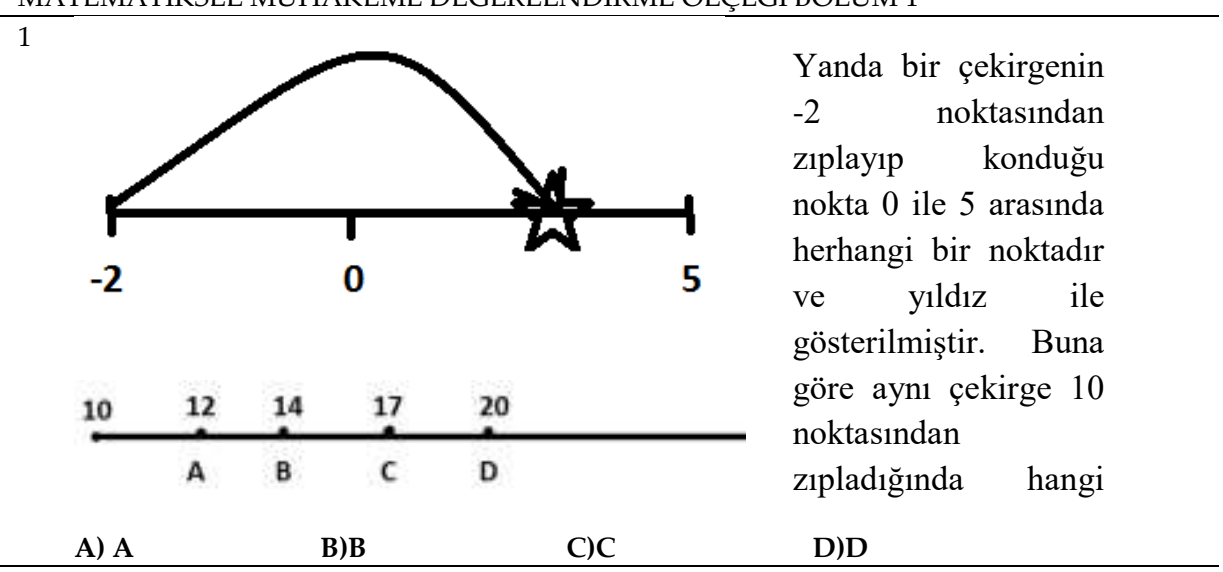


2 Meryem sayı doğrusunda sıfırın sağında 6 da, Zehra ise sıfırın solunda 4'tedir. Her ikisi de birbirlerine doğru iki adım yaklaşırlarsa aralarında kaç birim uzaklık kalır?

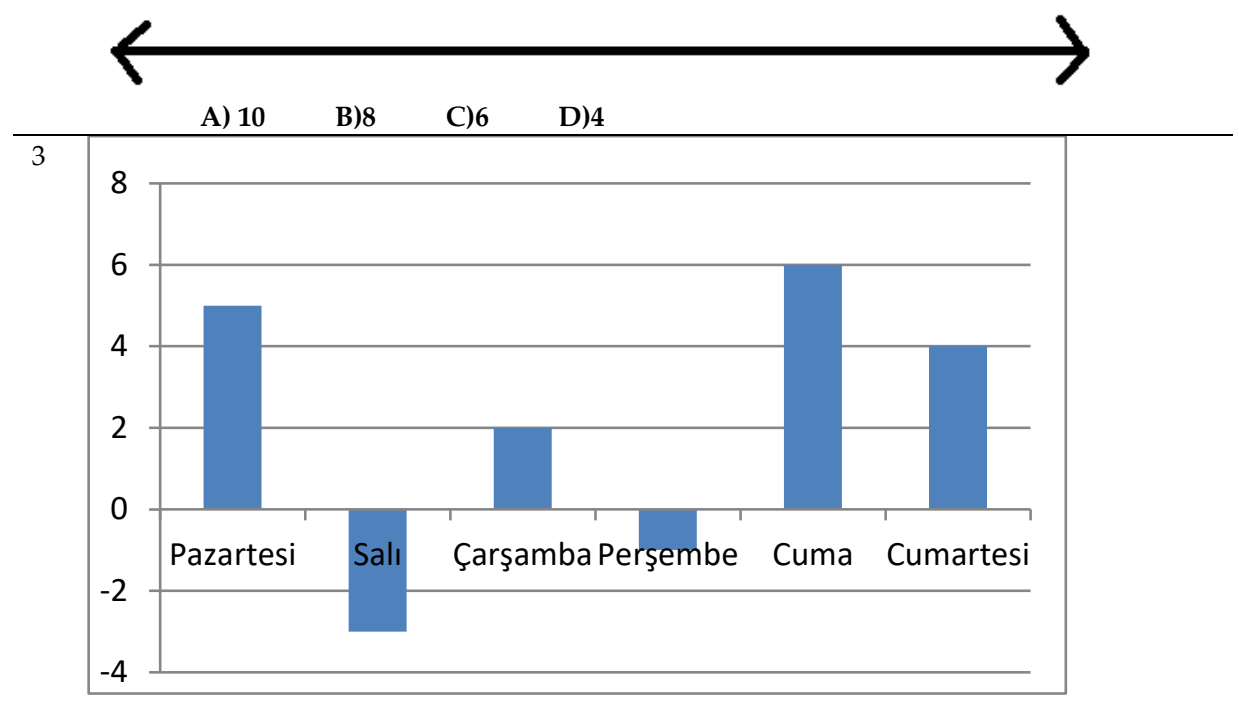

Yukarıda verilen grafikte sıcaklık farkının en az ve en çok olduğu ard arda gelen günler sırası ile hangisinde doğru olarak verilmiştir?

\section{En az}
A) Pazartesi- Salı
B) Çarşamba- Perşembe
C) Cuma- Cumartesi
D) Salı- Çarşamba

En çok

Cuma-Cumartesi

Perşembe- Cuma

Pazartesi- Salı

Perşembe-Cuma

Yandaki şekilde verilen sayılardan karşılıklı olanlar kendi aralarında bir kurala göre dizilmişlerdir. Bu örüntünün kuralına göre ? yerine kaç gelmelidir?
A) -9
B) -8
C) 3
D) 9

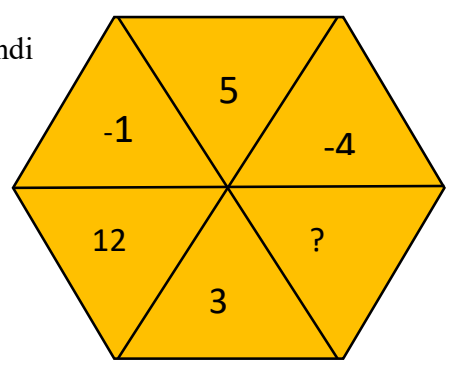




\begin{tabular}{|c|c|c|c|c|c|c|c|}
\hline 1. satır & (D) & E & 0 & $\mathbf{A}$ & - & $\Delta \square$ & Yanda verilen örüntüde satır- \\
\hline 2. satır & $\square$ & (9) & $\mathbf{0}$ & $\mathrm{O}$ & $\Delta$ & - & lar arası geçiş belli bir kurala \\
\hline 3. satır & $\Delta$ & $\square$ & 9 & 回 & 0 & & göre ise en alt satıra gelecek \\
\hline 4. satır & $?$ & $?$ & $?$ & $?$ & & & şekil hangisidir? \\
\hline
\end{tabular}
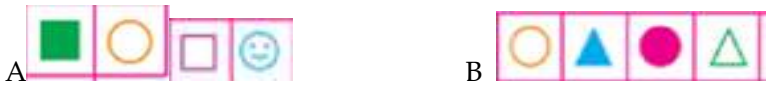

c 미이잉

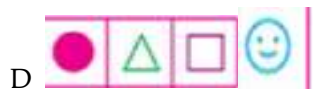

6 "Denizin 24 metre derinliğinde bulunan bir balık 12 metre daha derine indiğinde bulunduğu konum hangi tam sayı ile ifade edilir?" sorusunun çözümü adım adım verildiğinde ilk hata hangi adımda yapılmıştır?

1. adım: İlk durumda balığın konumu -24'tür.

2. adım: Yine aşağı indiğinden dolayı gidilen konumu (-12) olarak ifade edebiliriz.

3. adım: Bulunduğu konumdan aşağıya doğru indiği konumu çıkarırız.

$(-24)-(-12)=$

4. adım: $-24+12=-12$ olur.
A)1. adim
B)2. adım
C)3. adım
D)4. adım

7 Aşağıda verilen tam sayıları sıralarken bir hata yapılmıştır, yapılan hatanın aşağıda verilen kurallardan hangisine uymadığını belirleyiniz.

$-1<-2<-7<-100<0<2<5<8<10$

A) Pozitif sayılar 0'ın sağında yer almalıdır, Çünkü pozitif sayılar daima 0'dan büyüktür.

B) Negatif sayılar 0'ın solunda yer almalıdır, Çünkü negatif sayılar daima 0'dan küçüktür.

C) Pozitif sayılar 0'dan uzaklaştıkça değeri artar.

D) Negatif sayılar 0'dan uzaklaştıkça değeri azalır.

8 Aşağıdaki verilen ifadelerin bazısı "Her zaman", bazısı "Bazen" doğrudur, bazısı ise "Asla" doğru değildir. İfadeleri okuyup doğru şıkkı işaretleyiniz.

i. Sıfır negatif sayılardan daha büyüktür.

ii. Bir negatif sayı tersinden daha büyüktür.

iii. Negatif sayıların tersi 10 'dan daha azdır.

\begin{tabular}{lll}
\multicolumn{1}{c}{ I. } & \multicolumn{1}{c}{ II. } & III. \\
\hline A. Bazen & Her zaman & Asla \\
B. Her zaman & Asla & Bazen \\
C. Asla & Bazen & Her zaman \\
D. Her zaman & Bazen & Asla
\end{tabular}


9 Aşağıdaki verilen ifadelerin bazısı "Her zaman", bazısı "Bazen" doğrudur, bazısı ise "Asla" doğru değildir. İfadeleri okuyup doğru şıkkı işaretleyiniz.

I. İki pozitif sayı toplanınca sonuç sıfır olur.

II. İki negatif sayı toplanınca sonuç negatif olur

III. Bir pozitif sayı ile bir negatif sayı toplanınca sonuç pozitif olur.

\begin{tabular}{lll}
\multicolumn{1}{c}{ I. } & \multicolumn{1}{c}{ II. } & III. \\
\hline A. Bazen & Her zaman & Asla \\
B. Her zaman & Asla & Bazen \\
C. Asla & Bazen & Her zaman \\
D. Asla & Her zaman & Bazen
\end{tabular}

$1025 \mathrm{~cm}$ derinliğindeki bir kavanoza konan pire, $4 \mathrm{~cm}$ zıplayıp $1 \mathrm{~cm}$ aşağı kaymaktadır. Bu pire en az kaç zıplamada yukarı çıkar?
A) 6
B)7
C) 8
D) 9

11 Bir sürahide ağzına kadar dolu su vardır. Sürahideki su, $250 \mathrm{ml}$ hacmindeki 6 bardağa boşaltığında sürahide bir miktar su kalmakta, $350 \mathrm{ml}$ hacmindeki 5 bardağa boşaltıldığında ise 4 bardak tam olarak dolmakta beşinci bardak ise tam dolmamaktadır. Buna göre sürahideki su miktarı kaç ml olabilir?
A) $1500 \mathrm{ml}$
B) $1700 \mathrm{ml}$
C) $1750 \mathrm{ml}$
D) $1800 \mathrm{ml}$

\section{MATEMATIKSEL MUHAKEME DEĞERLENDIRME ÖLÇEĞİ BÖLÜM 2}

1 Aşağıda verilen işlemlerin sonuçlarının negatif ya da pozitif olduğunu tahmin ediniz.

\begin{tabular}{|l|l|l|}
\hline & NEGATIF $(-)$ & POZITIF $(+)$ \\
\hline $449+849+(-977)$ & & \\
\hline$-445+(-354)+(-524)$ & & \\
\hline $832+533+(-200)$ & & \\
\hline$-860+517+(-443)$ & & \\
\hline
\end{tabular}

2 "a" ve "b" sayıları birbirinin toplamaya göre tersidir. "c" sayısı ise "b" ile sıfır arasında yer almaktadır. Buna göre "c" nin toplamaya göre tersi sayı doğrusunda nerede yer alır? Çizerek açıklayınız.

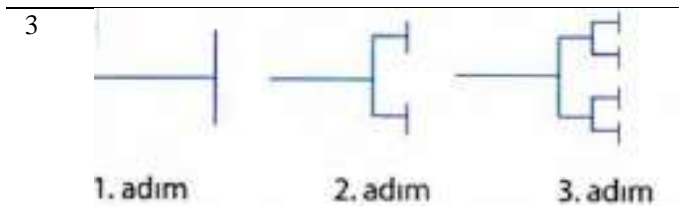

Yukarıda ilk üç adımı verilen örüntünün 4. adımını aşağıya çiziniz. 
4 4-(-6) İşleminin sayı doğrusu üzerinde gösterilişi aşağıdaki gibidir. İfadenin gösterilişinin yanlış olduğunu düşünüyor iseniz aşağıda verilen sayı doğrusu üzerinde işlemin doğrusunu gösteriniz, doğru olarak gösterildiğini düşünüyor iseniz yanına "doğru gösterilmiştir" yazınız.

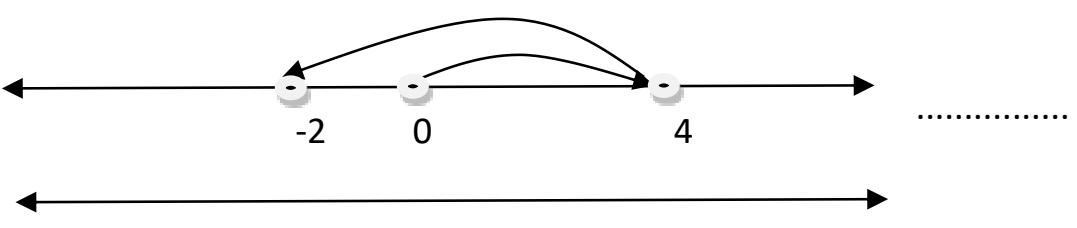

ก

5 Aşağıda verilen boşluklara işlem yapmadan akıl yürüterek " $<,>$ veya $="$ ifadelerinden uygun olanını koyunuz. karşılaştırdığınız işlemlerin sonuçlarına da bakarak, verilen kuralda boş bırakılan yerleri uygun sözcüklerle doldurunuz.

$$
\begin{aligned}
& 6-(-2) \ldots \ldots \ldots 6 \\
& 7-(-8) \ldots \ldots \ldots .7 \\
& -3-(+4) \ldots \ldots \ldots-3 \\
& -5-(+5) \ldots \ldots \ldots-5
\end{aligned}
$$

Kural: Bir sayıdan .işaretli bir sayı çıkarsa değeri artar, işaretli bir sayı çıkarsa değeri azalır.

$6 \quad$ Büyük bir apartmanda oturduğunuzu düşünün, dedeniz 4 kat üstünüzde, kuzeniniz dedenizin 6 kat altında oturuyor. Bu duruma ait dikey bir sayı doğrusu çiziniz ve 0 noktasını kendi oturduğunuz yer kabul ediniz.

- En iyi arkadaşınız, kuzeninizin 3 kat üstünde oturuyor ise sizin dairenize göre nerede oturmaktadır?

- Kuzeniniz, sizin dairenizin kaç kat altında ya da üstünde oturmaktadır?

$$
\circ
$$

$7 \quad 36$ metre uzunluğundaki bir ipi 2 parçaya bölmeniz isteniyor. Parçalardan büyük olanı, küçük parçanın 3 katı olmalıdır. Ancak bunu ölçebilecek hiç bir alet elinizde yok ise bunu nasıl en doğru şekilde yapabiliriz? Açıklayınız.

8 Bir santimetrelik uzunluğu ölçmek istiyorsunuz ancak elinizde sadece aşağıda gösterilen uzunluktaki çubuklar mevcut ise ve bunların haricinde hiç bir ölçü aletine sahip değil iseniz bu ölçümü nasıl yapabiliriz? Açıklayınız.

$5 \mathrm{~cm}$ :

$7 \mathrm{~cm}:$

$13 \mathrm{~cm}$ :

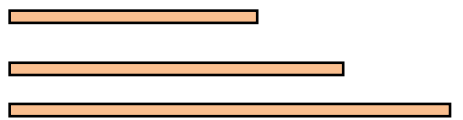


$9 \quad \ldots \ldots \ldots .+\ldots \ldots .+\ldots \ldots \ldots . . . \quad=? \quad$ Yanda verilen işlemde sonucun en büyük olabilmesi için aşağıda verilen sayılardan 3 tanesini seçip nasıl yerleştirmeliyiz? Hangi sayıları seçtiğinizi ve seçtiğiniz sayıların yerlerine karar verirken ne düşündüğünüzü açıklayınız.

2, $\quad 4, \quad 5, \quad 8, \quad 10$

10 Aşağıda verilen sayılardan üç tanesini seçiniz ve sadece birer kez (+) ve (-) işlemini kullanarak sonucu pozitif yapmaya çalışınız. Seçtiğiniz sayıları ve yaptığınız işlemlerin nedenini kısaca açıklayınız.

$\begin{array}{lllll}(-2) & (-13) & (-20) & (-14) & (-7)\end{array}$

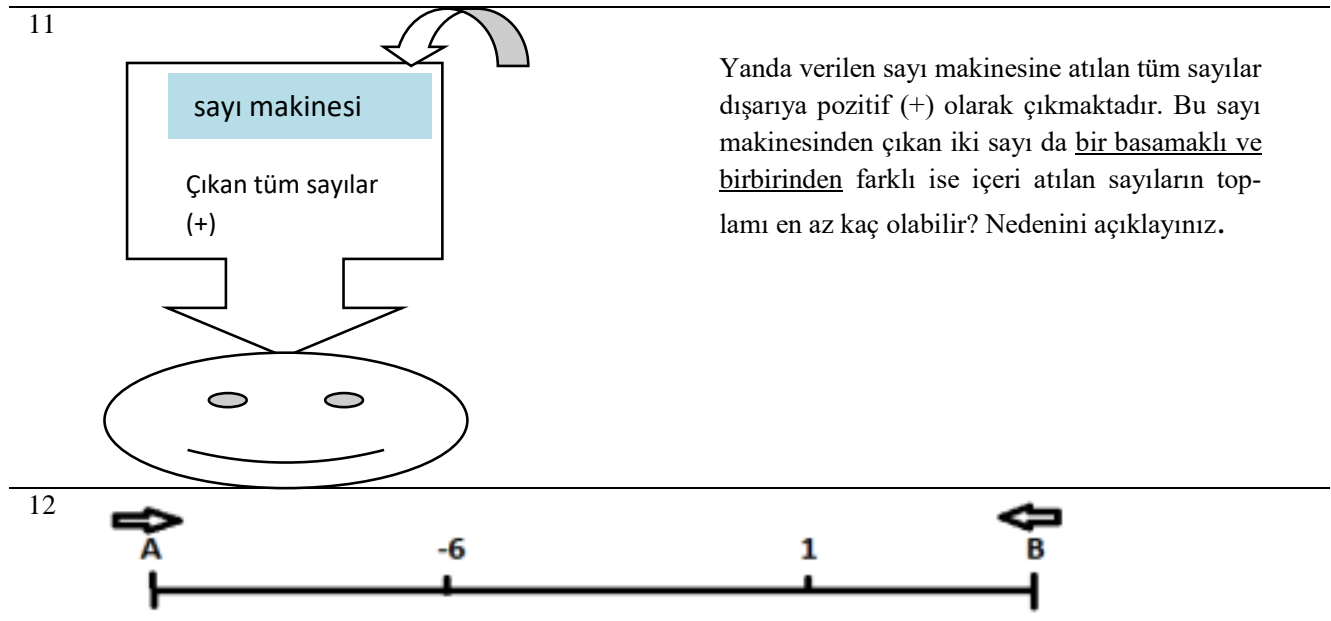

Şekilde görüldüğü gibi A ve B araçları birbirlerine doğru yola çıtıktan bir süre sonra mola vermişlerdir. A aracındaki kişi mola verdiği yerin (-6) noktasına olan uzaklığını 4 km olarak belirtmiş, B aracındaki kişi de aynı şekilde mola verdiği yerin (1) noktasına olan uzaklığını 4 km olarak belirtmiş ancak (1) noktasını geçip geçmediğini belirtmemiştir. Araçların mola vermeden önce karşılaşmış olma ihtimalleri var mıdır? A ve B araçları arasındaki mesafe kaç km olabilir? Çözümünüzü açıklayınız.

\section{Kaynakça Bilgisi / Citation Information}

Çoban, H. ve Tezci, E. (2020). Matematiksel muhakeme becerileri değerlendirme ölçeğinin geliştirilmesi. OPUS-Uluslararası Toplum Araştırmaları Dergisi, 15(24), 2805-2837. DOI: 10.26466/opus.610197 